\title{
EFEKTIVITAS MUSIK KLASIK DALAM MENURUNKAN \\ KECEMASAN MATEMATIKA (MATH ANXIETY) \\ PADA SISWA KELAS XI
}

\author{
Devi Winja Susanti \& Faridah Ainur Rohmah \\ Fakultas Psikologi \\ Universitas Ahmad Dahlan \\ Jalan Kapas No. 9 Yogyakarta \\ faridahainur@yahoo.com.
}

\begin{abstract}
This study aims to determine the effectiveness of classical music in reducing math anxiety. The participants in this study were 14 public high school students from class XI at Department of Social Sciences (IPS) which has an average to above average IQ scores and high to very high levels of anxiety. Data collection tool used Mathematics Anxiety Scale andEvaluation Music Sheet. This study used a pretest-posttest experimental with control group design. Random used in this study was a matching system. Data analysis in this study used Wilcoxon test. The results of data analysis showed significant decrease in scores between pretest and posttest in the experimental group $(\mathrm{KE})$ with $\mathrm{p}=0.014$. This result indicated that classical music was effective in reducing math anxiety in students. Math anxiety might decline as the students listen to classical music while learning mathematics.
\end{abstract}

Keywords: Classical Music, Math Anxiety, Student of High School.

\begin{abstract}
Abstrak
Penelitian ini bertujuan untuk mengetahui efektivitas musik klasik dalam menurunkan kecemasan matematika. Subyek dalam penelitian ini menggunakan siswa SMA Negeri 5 Yogyakarta kelas XI jurusan Ilmu Pengetahuan Sosial (IPS) yang memiliki skor IQ rata-rata dan di atas rata-rata serta tingkat kecemasan tinggi dan sangat tinggi yang berjumlah 14 orang. Pengumpulan data menggunakan Skala Kecemasan Matematika dan Lembar Evaluasi Musik. Penelitian ini menggunakan rancangan eksperimen pretest-posttest control group design. Random yang digunakan adalah sistem matching. Analisis data dalam penelitian ini
\end{abstract}


menggunakan analisis uji Wilcoxon. Hasil analisis data menunjukkan ada penurunan skor yang signifikan antara pretest dan posttest pada kelompok eksperimen (KE) dengan $\mathrm{p}=0,014$ yang mengindikasikan musik klasik efektif dalam menurunkan kecemasan matematika pada siswa. Kecemasan matematika dapat menurun seiring siswa mendengarkan musik klasik sambil belajar matematika.

Kata Kunci : Kecemasan Matematika, Musik Klasik, Siswa SMA.

\section{Pendahuluan}

Pemerintah Indonesia pun hingga saat ini masih menjadikan matematika sebagai mata ujian nasional dalam memperoleh kelulusan sekolah. Besarnya presentase siswa yang tidak lulus pada tahun 2010 adalah 10,12\%. Presentase tersebut menginformasikan terdapat 154.051 siswa SMA/MA yang tidak lulus dari 1.522.156 total siswa yang mengikuti UN. Menurut Kemendiknas (2010) terdapat 105.862 siswa jurusan Ilmu Pengetahuan Sosial (IPS) yang tidak lulus pada tahun 2010. Jumlah siswa ini adalah jumlah siswa terbanyak di antara ketiga jurusan satuan pendidikan lainnya, yaitu Ilmu Pengetahuan Alam (IPA), Agama, dan Bahasa.

Pemerintah memberikan penjelasan pada Salinan Peraturan Menteri Pendidikan nomor 75 pasal 7 (2009) mengenai sistem perbaikan bagi siswa yang tidak lulus UN. Siswa yang tidak lulus UN diperbolehkan mengikuti ujian ulangan pada mata ujian yang dinyatakan tidak lulus tersebut. Kemendiknas (2010) menyatakan presentase siswa yang mengulang UN menurut jenis mata pelajaran yang diulang di seluruh Indonesia, terutama siswa jurusan IPS. Matematika menjadi mata pelajaran yang paling banyak dipilih untuk diulang siswa jurusan IPS pada tingkat nasional sebesar 21,3\%. Siswa jurusan IPS di Daerah Istimewa Yogyakarta pun paling banyak memilih Matematika sebagai mata pelajaran yang diulang dengan presentase sebanyak 22,9\% dari lima mata pelajaran yang lain, yaitu Bahasa Indonesia, Bahasa Inggris, Ekonomi, Sosiologi, dan Geografi.

Timbul pertanyaan mengenai permasalahan atau alasan terjadinya fenomena di atas. Sebenarnya permasalahan dapat datang dari berbagai macam alasan, salah satunya adalah kecemasan. Hurlock (2000) mengemukakan bahwa rasa cemas merupakan keadaan mental yang tidak enak berkenaan dengan sakit yang mengancam atau yang dibayangkan. Menurut Drajat (1995), kecemasan merupakan perasaan yang tidak menentu, panik, takut tanpa mengetahui sesuatu yang ditakutkan dan 
tidak dapat menghilangkan perasaan gelisah serta mencemaskan tersebut. Reaksi cemas sebenarnya wajar bila disebabkan oleh keadaan yang menimbulkan stres yang jelas (Supratiknya, 1995). Kecemasan yang berlebihan akan memberikan dampak yang tidak baik untuk seseorang, salah satunya menurunnya prestasi.

Menurut APA(Association Psychology of America), anxiety atau rasa cemas merupakan keadaan suasana-perasaan $(\mathrm{mood})$ yang ditandai oleh gejala-gejala jasmaniah seperti ketegangan fisik dan kekhawatiran tentang masa depan (Durand, 2006). King (2008) menyatakan bahwa gangguan kecemasan merupakan salah satu gangguan psikologis yang diikuti oleh ketegangan otot, hiperaktif, dan kegelisahan pikiran.

Kecemasan matematika (mathematics anxiety) didefinisikan oleh Suinn dan Edwards (Campbell, 2005) sebagai perasaan tegang, kekhawatiran atau ketakutan yang mengganggu prestasi matematika seseorang. Selain itu, Ashcraft dan Faust (Campbell, 2005) memberikan pengertian bahwa kecemasan matematika adalah perasaan tertekan, kegelisahan bahkan ketakutan yang tercampur dengan kesalahan yang luar biasa pada angka dan memecahkan soal matematika. Menurut Tobias (1993) kecemasan matematika merupakan respon emosional terhadap matematika saat mengikuti kelas matematika, menyelesaikan masalah matematika, dan mendiskusikannya.

Dalam hal ini matematika dianggap sulit oleh siswa dikarenakan adanya beberapa faktor yang mempengaruhi. Berdasarkan hasil penelitian Ali (2009), ada tiga faktor dalam proses belajar mengajar yang dapat menimbulkan kecemasan, yaitu faktor pengelolaan kelas, disiplin kelas, dan penyajian materi pelajaran. Menurut Santosa (Unjianto, 2008) pada proses belajar matematika di sekolah, guru cenderung melakukan tiga hal, yaitu guru menuliskan teori di papan tulis, dilanjutkan contoh penerapan teori dalam menyelesaikan soal, sementara siswa mencatat materi yang dijelaskan guru. Kedua, guru menuliskan soal-soal di papan tulis dan siswa diminta mengerjakan, dan ketiga guru meminta siswa untuk menuliskan hasil pekerjaannya di papan tulis. Kondisi demikian bagi siswa yang pandai tidak menjadi masalah, tetapi bagi siswa yang kurang memiliki kompetensi matematika atau membenci matematika, keikutsertaannya dalam proses belajar mengajar dalam kondisi seperti itu tidak menyenangkan.

Adams (2001) berpendapat mengenai simtom kecemasan matematika, yaitu:

a. Bernafas berlebihan atau sering menahas nafas;

b. Berkeringat dingin selama menahan nafas;

c. Tubuh gemetar tidak terkontrol; 
d. Meletakkan pensil di belakang telinga;

e. Menghisap ibu jari tangan dan/atau mengigit-gigit kuku jari tangan;

f. Jantung berdetak dengan cepat;

g. Mengalami halusinasi dan rasa tidak berdaya, seolah-olah terjadi perang antara siswa dan angka matematika;

h. Merasa pusing diliputi dengan ketidakberdayaan siswa dalam mengerjakan matematika dan merasa bahwa angka atau rumus matematika itu tidak akan pernah selesai;

i. Siswa merasa ingin keluar dari situasi seperti di atas namun tidak bisa karena harus menyelesaikan soal matematika.

Brody (2003) juga memberikan pendapat mengenai simtom kecemasan matematika. Di bawah ini terdapat beberapa simtom kecemasan matematika menurut Brody, antara lain:

a. Panik, siswa memiliki perasaan tidak berdaya. Siswa mengalami kesulitan yang berat dan merasa sudah di ambang batas maksimal pada pelajaran matematika;

b. Paranoia, siswa berpikir bahwa semua orang tahu jawaban dari soal matematika kecuali dirinya. Siswa merasa seperti orang bodoh selama bertahun-tahun dan semua orang tahu akan hal itu;

c. Pasif, siswa bersikap seolah-olah tidak bisa berbuat apa-apa lagi untuk memperbaiki prestasinya dan tidak melakukan usaha apapun untuk itu;

d. Kurang percaya diri, siswa tidak percaya dengan kemampuan mereka. Siswa lebih mengandalkan menghafal rumus daripada memahami konsep matematika.

Kecemasan matematika bisa muncul sedini mungkin seperti pada anak-anak kelas empat SD dan puncaknya berada di sekolah menengah pertama (SMP) dan sekolah menengah atas. Scarpello (2007) menyebutkan beberapa faktor yang dapat mempengaruhi timbulnya kecemasan matematika, yaitu (a) Pengalaman masa lalu yang buruk; (b) Lingkungan kelas; (c) Pola Asuh Orangtua; dan (d) Kemampuan mengingat matematika yang buruk.

Scarpello menyebutkan pengalaman masa lalu yang buruk sebagai faktor pengaruh kecemasan. Hunsley (Cassady, 2010) juga menjelaskan adanya faktor pengaruh pengalaman masa lalu yang buruk sebagai faktor kecemasan. Pengalaman masa lalu menurut Hunsley dapat berupa kurang siapnya siswa atau pikiran buruk siswa mengenai ujian matematika dapat menjadi pemicu timbulnya kecemasan. Menurutnya, kecemasan matematika datang saat ujian matematika yang disebabkan oleh waktu ujian yang dibatasi dan siswa mengetahui konsep ujian matematika, yaitu untuk mengeukur kemampuan mereka. Oleh sebab itu, siswa mendapat nilai buruk 
di mata pelajaran matematika.

Syah (2005) menjelaskan adanya faktor-faktor yang mempengaruhi kesulitan belajar yang dapat menimbulkan kecemasan, yaitu:

a. Faktor Internal Siswa, yang meliputi gangguan atau ketidakmampuan psikofisik siswa yang dapat bersifat kognitif (rendahnya intelektual/inteligensi siswa), afektif (labilnya emosi dan sikap), dan psikomotor (terganggunya alat indera siswa).

b. Faktor Eksternal, yang meliputi semua situasi dan kondisi lingkungan sekitar siswa (lingkungan keluarga, masyarakat, dan sekolah);

c. Kejenuhan Belajar, yaitu rentang waktu tertentu yang digunakan untuk belajar, tetapi tidak mendatangkan hasil (Reber dalam Syah, 2005).

d. Kelelahan, dapat menjadi faktor pemicu kecemasan matematika karena siswa tidak dapat melanjutkan proses belajarnya yang sudah pada batas kemampuan jasmaniahnya.

Penjelasan Syah di atas menyatakan adanya faktor eksternal, berupa lingkungan sebagai faktor kecemasan. Faktor lingkungan ini juga dijelaskan oleh Dimyati \& Mudjiono (2009) sebagai faktor yang mempengaruhi proses belajar-mengajar, terutama matematika.

Menurut Susanto (2006), faktor lingkungan dapat berupa suara. Siswa dapat menerima pelajaran matematika dengan baik apabila tidak ada suara-suara berisik atau yang mengganggu. Siswa akan terganggu apabila terdengar suara-suara berisik sehingga merasa tidak nyaman di kelas dan dapat mempengaruhi timbulnya kecemasan pada siswa. Ada pula suara yang dapat meningkatkan belajar siswa, seperti musik yang dapat mempengaruhi kinerja otak dan musik yang menenangkan. Suara yang menenangkan dan/atau mempengaruhi kinerja otak dapat mencegah kesulitan belajar akibat kecemasan dalam proses pembelajaran matematika.

Banyak metode pembelajaran maupun coping dalam proses belajar mengajar matematika. Salah satunya adalah penggunaan musik oleh ilmuwan dari timur tengah, Al-Farabi (Sanif, 2008). Di dalam bukunya, Great Book About Music Al-Farabi mengatakan bahwa musik membuat rasa tenang/nyaman, sebagai pendidikan moral, mengendalikan emosi, pengembangan spiritual, dan menyembuhkan gangguan psikosomatik.

Musik kini telah banyak berkembang, mulai dari klasik sampai musik pop. Masing-masing genre memiliki fungsi dan manfaatnya. Merrit (2003) menyebutkan manfaat musik, antara lain:

a. Efek Mozart, adalah salah satu istilah untuk efek yang bisa dihasilkan sebuah musik yang dapat meningkatkan intelegensi seseorang; 
b. Refreshing, pada saat pikiran seseorang sedang kacau atau jenuh, dengan mendengarkan musik walaupun sejenak, terbukti dapat menenangkan dan menyegarkan pikiran kembali;

c. Motivasi, adalah hal yang hanya bisa dilahirkan dengan feeling tertentu. Motivasi ini dapat memunculkan semangat dan segala kegiatan bisa dilakukan. Tejwani (Merrit, 2003) juga mengamati bahwa musik menurunkan tekanan jiwa yang diakibatkan oleh olahraga;

d. Perkembangan kepribadian, kepribadian seseorang diketahui mempengaruhi dan dipengaruhi oleh jenis musik yang didengarnya selama masa perkembangan;

e. Terapi, terapi musik dapat menawarkan stimulus dan aktivitas yang memanfaatkan gaya belajar dan area-area di dalamnya yang dianjurkan dalam pendekatan kognitif, menyediakan lingkungan yang terstruktur untuk interaksi sosial dan generalisasi tujuan bahasa dan bicara, serta menyediakan lingkungan yang menyenangkan dan memotivasi untuk belajar (Gfeller, dalam Lefevre, 2010).

Haynes (2003) menemukan musik berefek positif bagi peserta Math Anxiety Test. Haynes meneliti pengaruh musik sebagai pengiring saat siswa Universitas West Virginia jurusan Algebra belajar selama 10 menit sebelum ujian semester dimulai. Haynes mengukur kecemasan matematika pada siswa tersebut dengan menggunakan Math Anxiety Rating Scale (MARS) yang disajikan dua kali, yaitu sebelum ujian (pretest) dan setelah ujian (posttest). Hasil analisis data menyebutkan bahwa rerata skor MARS pada kelompok kontrol yang tidak diperdengarkan musik pada pretest adalah sebesar 67,05 dan pada posttest sebesar 66,87. Selisih di antara pretest dan posttest pada kelompok kontrol adalah 0,18 sedangkan pada kelompok eksperimen yang diberikan musik sebesar 4,19. Selisih pada kelompok eksperimen tersebut didapat dari rerata pretest skor MARS yang sebesar 66,26 dan rerata posttest sebesar 62,07. Perbandingan selisih rerata skor MARS ini membuktikan bahwa musik dapat menurunkan kecemasan siswa jurusan Algebra Universitas West Virgina.

Musik juga dapat mempengaruhi penurunan depresi pada mahasiswa. Hal ini dibuktikan oleh Lerik \& Prawitasari (2005) yang meneliti sekelompok mahasiswa yang mengalami depresi. Hasilnya, musik sebagai media terapi mampu menurunkan tingkat depresi setelah pelaksanaan satu bulan. Musik yang dipakai pun dalam menurunkan gangguan neurotik, salah satunya kecemasan, dapat bermacam-macam. Musik yang dapat memberikan ketenangan dan kedamaian adalah musik dengan tempo yang lebih lambat (Rachmawati, 2005). Musik dengan tempo lambat tersebut dapat ditemukan dalam semua genre, salah satunya adalah musik klasik. 
Banyak penulis mengkaji tentang pengaruh musik terutama musik klasik sebagai media penyembuhan dan peningkatan kualitas individu/ kelompok. Hal ini dapat memberikan gambaran adanya hubungan antara musik dengan respon seseorang yang sebenarnya tidak jauh dari hubungan emosi antar musik dan pendengar (Djohan, 2005). Oleh karena itu, pendengar dapat merasakan ketenangan maupun kedamaian dengan mendengarkan musik secara tiba-tiba.

Berdasarkan penjelasan di atas,muncul pertanyaan apakah musik klasik dapat efektif sebagai sarana untuk menurunkan kecemasan mempelajari matematika (Math Anxiety) pada siswa kelas XI SMA Negeri 5 Yogyakarta jurusan IPS?

\section{Metode Penelitian}

Populasi pada penelitian ini adalah 115 siswa XI SMA Negeri 5 Yogyakarta jurusan Ilmu Pengetahuan Sosial yang memiliki tingkat inteligensi rata-rata (skor IQ 100-109), di atas rata-rata (skor IQ 110-119), dan memiliki kecemasan matematika (math anxiety) serta memiliki fungsi pendengaran yang baik. Teknik pengambilan sampel yang digunakan dalam penelitian ini adalah matching. Macthing merupakan teknik pengambilan sampel yang dilakukan saat randomisasi tidak mungkin dapat dilakukan, seperti subyek yang terlalu kecil (Brink \& Wood, 1994). Tujuannya adalah untuk menentukan subyek-subyek yang masuk ke dalam kelompok kontrol dan eksperimen. Teknik matching yang dilakukan pada penelitian ini adalah dengan memasangkan skor IQ terendah hingga tertinggi pada kelompok eksperimen dan kelompok kontrol. Hal itu dilakukan agar terdapat kesamaan distribusi skor IQ pada masing-masing kelompok.

Penelitian ini menggunakan eksperimen dengan metode eksperimen murni dengan desain pretest-posttest control group design, yaitu salah satu desain ekperimen yang dilakukan dengan jalan melakukan pengukuran atau observasi awal sebelum perlakuan diberikan dan setelah perlakuan pada kelompok perlakuan dan kelompok kontrol (Latipun, 2006).

\begin{tabular}{cccc}
\hline $\mathrm{KE}$ & $\mathrm{Y} 1$ & $\mathrm{X}$ & $\mathrm{Y} 2$ \\
\hline $\mathrm{KK}$ & $\mathrm{Y} 1$ & - & $\mathrm{Y} 2$ \\
\hline
\end{tabular}

Gambar 1. Bagan Rancangan Ekperimen

Pengukuran awal dan akhir dilakukan dengan menggunakan skala kecemasan 
matematika. Selain itu, metode observasi dan wawancara juga dilakukan untuk melakukan konfirmasi hasil penelitian kuantitatif dengan hasil penelitian kualitiatif.

Alat untuk memberikan perlakuan berupa memperdengarkan musik klasik kepada subyek adalah data berformat Windows Media Audio (wma) yang berdurasi 10.05 menit. Musik klasik ini diperdengarkan melalui alat pemutar musik, yaitu Windows Media Player 11 dan speaker yang disediakan oleh sekolah. Pada musik yang berdurasi 10.05 menit itu, terdapat dua lagu yang disusun oleh penulis, yaitu $4^{\text {th }}$ Symphony karya Mozart dan Canon in D minor karya Pachelbel. Metode analisis data yang digunakan dalam penelitian ini adalah uji statistik nonparametrik Wilcoxon.

\section{Hasil dan Pembahasan}

Peneliti mendeskripsikan data pretest dan posttest subyek penelitian untuk melihat rerata skor kecemasan yang diperoleh pada saat pretest. Di bawah ini merupakan tabel perbandingan rerata skor pretest dan posttest pada kelompok eksperimen dan kelompok kontrol.

Tabel 1. Perbandingan Rerata Skor Pretest Math Anxiety dan Posttest Math Anxiety pada Kelompok Eksperimen dan Kelompok Kontrol

\begin{tabular}{lll}
\hline Kelompok & Pretest & Posttest \\
\hline Eksperimen & 85,50 & 36,00 \\
\hline Kontrol & 85,75 & 42,25 \\
\hline
\end{tabular}

Menurut tabel di atas, dapat dilihat bahwa terdapat selisih rerata pretest dan posttest kelompok eksperimen (KE) adalah sebesar 49,5. Selisih rerata pada kelompok kontrol (KK) antara skor pretest dan posttest adalah sebesar 43,5. Hasil perubahan skor kelompok kontrol maupun kelompok eksperimen pada pretest dan posttest dapat disimak pada tabel 2 .

Pengujian hipotesis pada penelitian ini menggunakan statistik nonparametrik. Hal ini dikarenakan oleh adanya syarat-syarat yang tidak terpenuhi untuk menggunakan pengujian statistik parametrik. Sebenarnya penelitian ini memiliki potensi untuk menggunakan pengujian statistik parametrik karena terpenuhinya syarat-syarat, yaitu distribusi data penelitian ini normal, varians kelompok pun sama atau homogen, dan sistem matching yang diakui sebagai sistem random dalam penentuan subyek dipakai pada penelitian ini. Ada satu syarat menurut Tomkins (2006) yang dapat 
menentukan pemakaian parametrik atau nonparametrik, yaitu jumlah subyek penelitian. Jumlah subyek yang kecil $(\mathrm{n}<30)$ sering dapat mengurangi ketepatan pengoreksian hipotesis nol (Ho) dan dapat meningkatkan error. Oleh karena itu, statistik nonparametrik untuk pengujian pada subyek kecil. Penelitian ini memiliki jumlah subyek penelitian yang terbatas $(n<30)$, yaitu tepatnya 14 orang yang terdiri dari delapan orang pada KK dan enam orang pada KE. Distribusi skor keempat belas subyek adalah normal, namun dapat dimungkinkan adanya error atau kebetulan saja. Oleh karena itu, peneliti memutuskan untuk menggunakan pengujian nonparametrik.

Tabel 2. Hasil Skoring Skala Math Anxiety Subyek Penelitian

\begin{tabular}{clllll}
\hline Subyek & Skor Pretest & Kategori & Skor Posttest & Kategori \\
\hline KE & 1 & 80 & Tinggi & 42 & Rendah \\
\cline { 2 - 5 } 2 & 84 & Sangat Tinggi & 36 & SangatRendah \\
\cline { 2 - 5 } 3 & 85 & Sangat Tinggi & 40 & SangatRendah \\
\hline 4 & 85 & Sangat Tinggi & 34 & SangatRendah \\
\hline 5 & 88 & Sangat Tinggi & 31 & SangatRendah \\
\hline KK & 91 & Sangat Tinggi & 33 & SangatRendah \\
\hline 1 & 75 & Tinggi & 40 & SangatRendah \\
\hline 2 & 80 & Tinggi & 39 & SangatRendah \\
\hline 3 & 83 & Sangat Tinggi & 39 & SangatRendah \\
\hline 4 & 84 & Sangat Tinggi & 38 & SangatRendah \\
\hline 5 & 85 & Sangat Tinggi & 44 & Rendah \\
\hline 6 & 90 & Sangat Tinggi & 38 & SangatRendah \\
\hline 7 & 93 & Sangat Tinggi & 43 & Rendah \\
\hline 8 & 96 & Sangat Tinggi & 57 & Normal \\
\hline
\end{tabular}

Hasil uji wilcoxon menunjukkan taraf signifikansi uji beda data (p) yang diperoleh adalah 0,028. Nilai tersebut merupakan nilai untuk tes two-tailed, sedangkan penelitian ini menggunakan one-tailed test. Oleh sebab itu, peneliti membagi dua nilai p dan mendapatkan nilai signifikansi (p) sebesar 0,014. Berdasarkan hasil tersebukti berarti Ho ditolak dan Ha diterima. Jadi, ada perbedaan skor skala kecemasan matematika pada pretest dan posttest pada kelompok eksperimen atau perlakuan yang diterima kelompok eksperimen efektif untuk menurunkan kecemasan matematika.

Bergantung pada hasil analisis di atas, yaitu musik klasik efektif untuk 
menurunkan tingkat kecemasan matematika dapat menegaskan teori-teori sebelumnya mengenai hubungan musik dan matematika. Haynes (2003) menjelaskan dalam penelitiannya mengenai efek musik sebagai pengiring pada tes kecemasan matematika bahwa musik dapat mengurangi skor tes tersebut, tetapi efek tersebut tidaklah ditemukan apabila musik yang didengar tidak sesuai dengan mekanisme sistem tubuh seseorang. Hal tersebut juga dinyatakan Sirait (2005) dalam penelitiannya bahwa musik menyerang sistem saraf pusat secara langsung dan akan mempengaruhi kognitif dan fisiologis subyek. Hubungan tersebut dinyatakan oleh Vanderbok (2007) bahwa musik klasik memiliki struktur yang teratur sehingga dapat menuntun otak untuk menyelesaikan masalah yang membutuhkan konsentrasi tinggi, salah satunya adalah pelajaran matematika. Setelah melihat hasil analisis di atas, dapat digambarkan bahwa subyek KE dapat mengatasi kesulitan dalam belajar matematika yang tentunya sangat berkaitan dengan fungsi kognitif subyek. Oleh karena itu, kecemasan matematika yang dialami oleh subyek KE dapat menurun.

Musik klasik memang memberikan pengaruh positif bagi subyek KE selama pelatihan maupun setelahnya. Pembuktian secara statistik di atas didukung oleh aspek kualitatif lainnya. Diskusi yang dilakukan peneliti tiap musik klasik menggambarkan bahwa musik klasik memberikan efek yang positif bagi subyek, yaitu merasakan tenang dan dapat berpikir jernih saat belajar menggunakan musik klasik. Mereka tidak lagi merasakan jantung berdebar kencang dan justru lebih fokus saat belajar matematika. Memang tidak semua subyek mendengarkan lagu pada waktu yang bersamaan dan saat belajar matematika, seperti prosedur yang telah diberikan oleh peneliti namun mereka merasa lebih bersemangat untuk belajar matematika. Hal tersebut dibuktikan saat diskusi bahwa subyek juga menyebutkan adanya suatu rangsangan yang memudahkan mereka untuk menjawab soal-soal matematika berasal dari musik klasik tersebut. Tempo yang lembut dan tampak megah pada lagu $4^{\text {th }}$ Symphony karya Mozart memberikan energi positif dan efek semangat bagi subyek. Selain itu, subyek merasa tenang pada lagu Canon in D minor karya Pachelbel yang bertempo lambat. Subyek berpendapat setelah mendengarkan lagu tersebut, kejenuhan dan perasaan yang kacau melebur seketika dan berganti dengan perasaan seimbang serta damai.

Pengaruh positif di atas tersebut telah dijelaskan pula pada teori Paget (2006). Paget menyatakan bahwa efek musik yang dapat terasa pada tubuh dan pikiran manusia adalah kekuatan otot, peningkatan energi, berpengaruh pada detak jantung, metabolisme, penurunan level stres, berkurangnya kelelahan, pemunculan karakter dan emosi seseorang, serta kreativitas seseorang. 
Musik klasik yang diperdengarkan juga bukanlah sembarang musik klasik. Peneliti memilih musik klasik dengan tempo lambat sehingga memiliki dampak positif seperti yang disampaikan oleh Djohan (2005) dan Rachmawati (2005). Seseorang harus berada dalam kondisi seimbang sehingga dapat mengakses pikiran dan pemahaman. Kondisi seimbang ini didapat ketika semua fungsi fisik seseorang melambat. Musik dengan tempo lambat memberikan efek positif bagi tubuh seseorang dan meningkatkan kualitas serta fungsi tubuh. Musik dengan tempo ini mampu memperlambat detak jantung yang bergerak cepat sehingga hal tersebut juga dapat dirasakan oleh subyek. Merrit (2003) juga menjelaskan mengenai manfaat musik sebagai refreshing dan motivasi. Menurutnya, musik menenangkan pikiran seseorang yang kacau atau jenuh dan dapat membangkitkan semangat sehingga segala kegiatan dapat dilakukan. Oleh karena itu, subyek merasa lebih fokus dalam belajar matematika.

Lembar evaluasi eksperimen maupun lembar evaluasi rumah yang dikerjakan oleh subyek KE menunjukkan bahwa subyek KE telah mendapat penurunan kecemasan sejak pertemuan pertama pelatihan Math Music. Penurunan kecemasan tersebut diperoleh subyek KE karena subyek KE mendapat efek musik klasik, yaitu rasa tenang dan fokus. Selama pelatihan, yaitu tanggal 14-25 Februari 2011, subyek KE telah merasakan efek musik klasik tersebut. Efek tenang langsung dirasakan subyek KE setelah satu kali mendengar musik klasik yang diperdengarkan peneliti pertemuan pertama pelatihan, yaitu tanggal 14 Februari 2011. Hal tersebut dituliskan oleh subyek KE pada lembar evaluasi musik yang dikerjakan pada pertemuan pertama pelatihan. Mereka menyatakan bahwa beban pikiran dan tekanan seusai sekolah yang mereka rasakan mulai berkurang. Hal itu tentunya adanya pengaruh pemilihan waktu pelatihan yang tepat, yaitu pukul 14.00-15.00 WIB. Menurut mereka, waktu siang merupakan waktu yang cocok bagi mereka mendengarkan musik tersebut sebab dapat mengurangi beban sekaligus menambah semangat serta energi untuk mengerjakan aktivitas lainnya. Keenam subyek KE menyatakan bahwa sudah menyukai musik tersebut sejak pertama kali diperdengarkan. Minat dan selera subyek KE inilah yang juga menentukan pemerolehan efek-efek musik klasik tersebut. Teori tersebut diungkap oleh Djohan (2005) bahwa musik akan lebih efektif memberikan manfaat dan efek positifnya pada pendengar saat pendengar menyukai musik tersebut. Pasalnya, bila pendengar sudah menyukai musik yang telah didengarnya, maka secara langsung musik tersebut masuk ke dalam sistem otak lalu merangsang sistem mekanisme tubuhnya. 


\section{Simpulan}

Hasil penelitian yang didapat setelah dianalisis dengan uji Wilcoxon menunjukkan bahwa dengan mendengarkan musik klasik dapat secara efektif menurunkan kecemasan matematika siswa. Ada perbedaan tingkat kecemasan matematika yang signifikan antara sebelum perlakuan (pretest) dan sesudah perlakuan (posttest) pada siswa. Siswa yang belajar matematika dengan mendengarkan musik klasik mengalami penurunan skor kecemasan matematika.

\section{Daftar Pustaka}

Adams, C. (2001). Overcoming Math Anxiety. Mathematically Bent. 23(1): 4950 .

Ali. F. (2009). Faktor faktor dalam Proses Belajar Mengajar. www.aliblog.blogspot.com/6787/faktor.html. 29 Oktober 2010.

Brink, P. \& Wood, M. (1994). Langkah Dasar dalam Perencanaan Riset Keperawatan. Jakarta: Buku Kedokteran EGC.

Brody, J. (2003). Problem Posing/Solving \& Linear Algebra. International Journal in Mathematics Education, Science and Technology. Volume 27: 103121.

Campbell, J.I.D. (2005). Handbook of Mathematical Cognition. New York: Psychology Press.

Cassady, J.C. (2010). Anxiety in Schools: The Causes, Consequences, and Solustions for Acedemic Anxieties. New York: Peter Lang Press.

Dimyati \& Mudjiono. (2009). Belajar dan Pembelajaran. Jakarta: Rineka Cipta. Djohan. (2005). Psikologi Musik. Yogyakarta: Buku Baik.

Drajat. (1995). Kesehatan Mental. Jakarta: Gunung Agung.

Durand. (2006). Intisari Psikologi Abnormal. Yogyakarta: Pustaka Pelajar.

Haynes, S.E. (2003). The Effect of Background Music on The Mathematics Test Anxiety of College Algebra Students. Disertasi. (tidak diterbitkan). West Virginia: Department of Educational Theory and Practice.

Hurlock. (2000). Psikologi Perkembangan Jilid 1. Jakarta: PT Gramedia Pustaka Utama. 
King, L.A. (2008). The Science of Psychology: An Appreciative View. New York: McGraw-Hill Higher Education.

Kementrian Pendidikan Nasional. (2010). Laporan Ujian Nasional (UN) Utama SMA dan MA (Madrasah Aliyah). 2010. Jakarta: Kementrian Pendidikan Nasional

Latipun. (2006). Psikologi Eksperimen. Malang: UMM Press.

Lerik, M.D.C. \& Prawitasari, J.E. (2005). Pengaruh Terapi Musik terhadap Depresi di antara Mahasiswa. Jurnal Sosiosains. 18 (2) April: 200219.

Lefevre, M. (2010). Communicating with Cildren and Young People: Making a Difference. Washington: Social Prentice Press.

Merrit, S. (2003). Simfoni Otak. Bandung: Penerbit Kaifa.

Paget, R.J. (2006). The Role of Music in Learning. United Kingdom: BAAT Ltd.

Rachmawati, Y. (2005). Musik sebagai Pembentuk Budi Pekerti. Yogyakarta: Panduan.

Salinan Peraturan Menteri Pendidikan Nasional No. 75 Tahun 2009 tentang Ujian Nasional SMP/MTs/SPMLB, SMA/MA/SMALB, dan SMK Tahun Pelajaran 2009/2010. Jakarta: Departemen Pendidikan Nasional RI.

Sanif, (2008). Terapi Musik. www.jantunghipertensi.com. 11 Oktober 2010.

Scarpello, G. (2007). Helping Students Get Past Math Anxiety. Techniques, Connecting Education and Careers (September): 34-35.

Schaefer, C.E. (2003). Play Therapy with Adults. New York: John Wiley and Sons.

Sirait, S.A.P. (2005). Efek Musik pada Tubuh Manusia. Majalah Warta Advent On-line (WAO). Edisi 12 Agustus 2005: 09- 11.

Supratiknya, A. (1995). Mengenal Perilaku Abnormal. Yogyakarta: Penerbit Grasindo.

Susanto, H. (2006). Meningkatkan Konsentrasi Siswa Melalui Optimalisasi Modalitas Belajar Siswa. Jurnal Pendidikan Penabur. No. 6 Tahun V: 46-51.

Syah, M. (2005). Psikologi Pendidikan dengan Pendekatan Baru. Bandung: Remaja Rosdakarya. 
Tobias, S. (1993). Overcoming Math Anxiety. New York: WW Norton.

Tomkins, C. (2006). An Introduction to Non-parametric Statistics for Health Scientists. University of Alberta Health Sciences Journal. Volume 3: 20-26.

Unjianto, B. (2008). Banyak Siswa Benci Pelajaran Matematika. http:// w w w. s u a r a m e r d e k a . c o m/ b e t a $1 / \mathrm{n}$ e w s / endtof.php?id_news=20382\&amp;title= Banyak\%20Siswa $\% 20$ Benci\%20Pelajaran\%20Matematika. 11 Oktober 2010.

Vanderbok, B. (2007). Benefits of Music Education to Math, Reading, Language and Spatial Intelligence. www.supportTMF.org. 29 Oktober 2010. 